\title{
Integrated Disease Management of Rice Blast Caused by Pyricularia grisea (Sacc.)
}

\author{
Ch. Varaprasada Rao* and P. Anil Kumar \\ Department of Plant Pathology, Agricultural College, Bapatla-522 101, India \\ *Corresponding author
}

\section{A B S T R A C T}

\begin{tabular}{|l|}
\hline K e y w o r d s \\
$\begin{array}{l}\text { Rice blast, Fungicides, } \\
\text { Plant extracts, Biocontrol } \\
\text { agents, Disease } \\
\text { Incidence, Yield }\end{array}$ \\
\hline Article Info \\
\hline $\begin{array}{l}\text { Accepted: } \\
\text { 24 February } 2018 \\
\text { Available Online: } \\
\text { 10 March } 2018\end{array}$ \\
\hline
\end{tabular}

\section{Introduction}

Rice (Oryza sativa L.) is the staple food for more than 60 per cent of the world's population and more than 90 per cent of the rice produced in the world is consumed in the Asian countries. Globally, during 2011-12 rice crop occupied an area of about 159.22 million hectares with 465.81 million tonnes of production and productivity of 4.36 metric tonnes per hectare (USDA, 2013).Among them, fungi alone account for more than thirty diseases of which rice blast caused by Pyricularia grisea Sacc is one of devastative and destructive diseases of rice worldwide, causing yield losses to the extent of $70-80 \%$ in various rice ecosystems (Ratna Madhavi, 2011). In recent times, rice blast has become one of the prevalent and major diseases on rice in Prakasam and Sri Potti Sreeramulu Nellore districts of Andhra Pradesh, causing heavy losses to the rice growing farmers. Therefore an attempt was made on integrated practices for managing blast disease in rice.

\section{Materials and Methods}

The field experiment was laid out during Kharif and Rabi, 2011-12 in Randomized Block Design (RBD) with nine treatments and each treatment replicated thrice using susceptible rice variety BPT 5204 at Krishi Vigyan Kendra, Darsi, Prakasam District on integrated management of blast by using fungicides, plant extracts and bio control agents. The treatments included seed treatment 
and foliar application of fungicides, bio control agents and plant extracts which were found effective under in vitro conditions. The treatments were tested alone and in different combinations with an untreated control. The data were recorded as Per cent Disease Severity (PDS) and grain yield.

The seeds of susceptible rice variety BPT 5204 were treated with carbendazim @ 2g/kg and the seeds were broadcasted in seed bed of one cent area.

Twenty five day old seedlings were transplanted to main field at a spacing of $15 \times 15 \mathrm{~cm}$ in $5 \times 2 \mathrm{~m}$ size plots with recommended dose of fertilizers. The fertilizer dose of $150 \mathrm{~kg} \mathrm{~N}, 60 \mathrm{~kg} \mathrm{P}_{2} \mathrm{O}_{5}$, and $50 \mathrm{~kg} \mathrm{~K} 2 \mathrm{O}$ was applied in all the plots. Half of the nitrogen and full dose of phosphorus and potash were applied just before transplanting as basal dose. The remaining nitrogen was top dressed in two equal splits at tillering and panicle initiation stages.

The treatments were applied at the initial stage of symptom development. Treatment details were given in Table 2 .

\section{Results and Discussion}

In the present investigation, seed treatment with carbendazim, foliar sprays with tricyclazole, $P$. fluorescens and Ocimum sanctum leaf extract were evaluated in possible combinations to assess the integrated effect of these combinations on leaf blast severity on susceptible variety BPT 5204. For comparison, resistant cv NLR 34449 was also included without any plant protection measures directed against leaf blast. Observations on leaf blast severity and grain yield were recorded and compared with unsprayed plots of BPT 5204. Field experiment was conducted during Kharif and Rabi 2011-12.

\section{Kharif 2011-2012}

The results of Kharif 2011-12 revealed that the lowest PDS (11.8\%) was recorded with resistant variety NLR 34449 (T2) followed by seed treatment with carbendazim @ 2g/kg + spraying tricyclazole@0.06\% twice at seven days interval, i.e., T9 (21.9\%) and seed treatment with carbendazim @ $2 \mathrm{~g} / \mathrm{kg}+$ spraying of tricyclazole @ $0.06 \%$ + spraying of P. fluorescens @ 0.4\%,i.e., T6 (26.2\%). The treatments involving seed treatment with carbendazim @2g/kg + one spray of tricyclazole@0.06\% spray (T3) and seed treatment with carbendazim @ $2 \mathrm{~g} / \mathrm{kg}+$ spraying of tricyclazole @ 0.06\% + spraying of plant extract of $O$. sanctum @ 15\% after 7 days of first spray and spraying of $P$. fluorescens@ @ $0.4 \mathrm{~g} / 1$ after 7 days of first spray (T8) resulted in $27.7 \%$ and $28.3 \%$ PDS respectively.

Seed treatment with carbendazim @ 2g/kg + foliar spray with P. fluorescens @ 0.4\% (T4), seed treatment with carbendazim alone @ $2 \mathrm{~g} / \mathrm{kg}$ (T1) and seed treatment with carbendazim @ 2g/kg + spraying of tricyclazole @ $0.06 \%+$ spraying of $O$. sanctum leaf extract @ 15\% (T7) resulted in $32.5 \%, 33.1 \%$ and $34.1 \%$ PDS. Seed treatment with carbendazim @ 2g/kg + foliar spray with O. sanctum @ 15\% (T5) recorded highest PDS of $35.8 \%$ among different treatments tested though it differed significantly when compared with untreated control (45.4\%) (T10).

Lowest grain yields were recorded in unsprayed treatment (T10) (2031 $\mathrm{kg} \mathrm{ha}^{-1}$ ) followed by seed treatment with carbendazim (a) $2 \mathrm{~g} / \mathrm{kg}+$ foliar spray with O. sanctum @ 15\% (T5) (2058 kg ha ${ }^{-1}$ ), seed treatment with carbendazim alone @ 2g/kg (T1) (2337 $\mathrm{kg} \mathrm{ha}^{-1}$ ) and seed treatment with carbendazim @ 2g/kg + spraying of tricyclazole @ $0.06 \%$ + spraying of plant extract of $O$. sanctum @ 
15\%+ spraying of P. fluorescens @ $0.4 \%$ $\left(2501 \mathrm{~kg} \mathrm{ha}^{-1}\right)$ (T8) with insignificant differences between them. Significantly superior grain yield was recorded in seed treatment with carbendazim @ $2 \mathrm{~g} / \mathrm{kg}+$ two sprays of tricyclazole @ 0.06\% at seven day interval (T9) (3809 $\left.\mathrm{kg} \mathrm{ha}^{-1}\right)$ followed by seed treatment with carbendazim @ 2g/kg + one spray of tricyclazole @ 0.06\% (T3) (3298 kg $\mathrm{ha}^{-1)}$.

Seed treatment with carbendazim @ 2g/kg + spraying of tricyclazole @ $0.06 \%+$ spraying of plant extract of $O$. sanctum @ 15\% (2556 $\mathrm{kg} \mathrm{ha}{ }^{-1}$ ) (T7), seed treatment with carbendazim @ $\mathrm{g} / \mathrm{kg}+$ spraying of tricyclazole @ $0.06 \%+$ spraying of $P$. fluorescens@0.4\% (2664 kg ha $\left.{ }^{-1}\right)(\mathrm{T} 6)$ and seed treatment with carbendazim @ $2 \mathrm{~g} / \mathrm{kg}+$ foliar spray with P. fluorescens @ 0.4\% (2731 $\mathrm{kg} \mathrm{ha}{ }^{-1}$ ) T4 had insignificant differences among themselves ().

\section{Rabi 2011-12}

The results of Rabi 2011-12 revealed that the highest PDS (55.3\%) was observed in untreated control plot (T10) followed by seed treatment with carbendazim @ 2g/kg + foliar spray with $O$. sanctum @ 15\% (T5) (53.3), seed treatment with carbendazim @ 2g/kg (T1) $(38.1 \%)$ and seed treatment with carbendazim @ $\mathrm{g} / \mathrm{kg}+$ spraying of tricyclazole@0.06\% + spraying of plant extract of O. sanctum @ 15\% (T7) (44.1\%).

The treatments involving seed treatment with carbendazim @ $2 \mathrm{~g} / \mathrm{kg}+$ spraying of tricyclazole @ $0.06 \%+$ spraying of $P$. fluorescens @ 0.4\% (T6) (31.9\%), seed treatment with carbendazim @ 2g/kg + one spray of tricyclazole @ 0.06\% (T3) (34.0\%), seed treatment with carbendazim @ 2g/kg + spraying of tricyclazole @ $0.06 \%+$ spraying of plant extract of $O$. sanctum @ 15\% after 7 days of first spray + spraying of $P$. fluorescens
@ $0.4 \mathrm{~g} / \mathrm{l}$ after 7 days of first spray (T8) (31.0\%) and seed treatment with carbendazim @ 2g/kg + foliar spray with P. fluorescens @ $0.4 \%$ (T4) $(34.8 \%)$ were found to differ insignificantly among themselves. The lowest PDS was observed with resistant variety NLR 34449 (T2) $11.2 \%$ followed by seed treatment with carbendazim @ 2g/kg + twice spraying of tricyclazole @ $0.06 \%$ at seven days interval (T9) $(22.2 \%)$ differed significantly with all other treatments but insignificant differences between them.

In unsprayed control plot (T10) grain yield was $2037 \mathrm{~kg} \mathrm{ha}^{-1}$. Treatments involving seed treatment with carbendazim @ 2g/kg + foliar spray with $O$. sanctum @ 15\% (T5) (2386 kg $\mathrm{ha}^{-1}$ ) followed by seed treatment with carbendazim @ $2 \mathrm{~g} / \mathrm{kg}+$ spraying of tricyclazole @ $0.06 \%$ + spraying of plant extract of $O$. sanctum @ 15\% after 7 days of first spray + foliar spray with $P$. fluorescens @ $0.4 \%$ (T8) $\left(2620 \mathrm{~kg} \mathrm{ha}^{-1}\right)$, seed treatment with carbendazim @2g/kg + spraying of tricyclazole@0.06\% + spraying of plant extract of O.sanctum@15\% (T7) (2735 kg $\mathrm{ha}^{-1}$ ) gave lesser grain yields with insignificant differences among themselves but significant difference with untreated control plot.

Significantly superior grain yield of $4217 \mathrm{~kg}$ $\mathrm{ha}^{-1}$ was recorded with seed treatment with carbendazim @ 2g/kg + twice spraying tricyclazole @ 0.06\% at seven days interval (T9). Seed treatment with carbendazim @ $2 \mathrm{~g} / \mathrm{kg}+$ foliar spray with $P$. fluorescens @ $0.4 \%$ (T4) $\left(2844 \mathrm{~kg} \mathrm{ha}^{-1}\right)$, seed treatment with carbendazim@2g/kg (T1) (2846 kg ha-1), seed treatment with carbendazim @ 2g/kg + tricyclazole@0.06\%) (T3) (3192 kg ha $\left.{ }^{-1}\right)$ and seed treatment with carbendazim @ 2g/kg + spraying of tricyclazole @ $0.06 \%+$ spraying of P.fluorescens @ 0.4\% (T6) (3231 kg ha ${ }^{-1}$ ) were next to $\mathrm{T} 9$ with significantly higher grain yields compared to untreated control but lesser than T9. 
Table.1 Integrated disease management of rice blast

\begin{tabular}{|c|c|c|c|c|c|c|c|}
\hline \multirow[t]{2}{*}{ S. No. } & \multirow[t]{2}{*}{ Treatments } & \multicolumn{3}{|c|}{ Per cent Disease Severity (PDS)* } & \multicolumn{3}{|c|}{ Yield $\left(\mathrm{kg} \mathrm{ha}^{-1}\right)$} \\
\hline & & $\begin{array}{c}\text { 2011-12 } \\
\text { Kharif }\end{array}$ & $\begin{array}{l}\text { 2011-12 } \\
\text { Rabi }\end{array}$ & $\begin{array}{l}\text { Pooled } \\
\text { Mean }\end{array}$ & $\begin{array}{c}\text { 2011-12 } \\
\text { Kharif }\end{array}$ & $\begin{array}{l}\text { 2011-12 } \\
\text { Rabi }\end{array}$ & $\begin{array}{l}\text { Pooled } \\
\text { Mean }\end{array}$ \\
\hline 1 & T1 - Seed treatment with carbendazim @2g/kg & $\begin{array}{c}33.1 \\
(35.1)\end{array}$ & $\begin{array}{c}38.1 \\
(38.1)\end{array}$ & $\begin{array}{c}35.6 \\
(36.6)\end{array}$ & 2337 & 2846 & 2592 \\
\hline 2 & T2 - Resistant variety (NLR 34449) & $\begin{array}{c}11.8 \\
(20.1)\end{array}$ & $\begin{array}{c}11.2 \\
(19.6)\end{array}$ & $\begin{array}{c}11.5 \\
(19.9)\end{array}$ & 3046 & 3070 & 3058 \\
\hline 3 & $\begin{array}{l}\text { T3 - Seed treatment with carbendazim @ 2g/kg + Foliar application } \\
\text { of tricyclazole @ } 0.06 \%\end{array}$ & $\begin{array}{c}27.7 \\
(31.8)\end{array}$ & $\begin{array}{c}34.0 \\
(35.4)\end{array}$ & $\begin{array}{c}30.8 \\
(33.7)\end{array}$ & 3298 & 3192 & 3245 \\
\hline 4 & $\begin{array}{l}\text { T4 - Seed treatment with carbendazim @ 2g/kg + foliar spray with } \\
\text { Pseudomonas fluorescens @ } 0.4 \%\end{array}$ & $\begin{array}{c}32.5 \\
(34.8)\end{array}$ & $\begin{array}{c}34.8 \\
(36.2)\end{array}$ & $\begin{array}{c}33.6 \\
(35.4)\end{array}$ & 2731 & 2844 & 2788 \\
\hline 5 & $\begin{array}{l}\text { T5 - Seed treatment with carbendazim @ 2g/kg + foliar spray with } \\
\text { Ocimum sanctum @ 15\% }\end{array}$ & $\begin{array}{c}35.8 \\
(36.8)\end{array}$ & $\begin{array}{c}53.3 \\
(46.9)\end{array}$ & $\begin{array}{c}44.5 \\
(41.8)\end{array}$ & 2058 & 2386 & 2222 \\
\hline 6 & $\begin{array}{l}\text { T6 - Seed treatment with carbendazim @ 2g/kg + spraying of } \\
\text { tricyclazole @ } 0.06 \%+\text { Spraying of Pseudomonas fluorescens } \\
\text { @ } 0.4 \% \text { after } 7 \text { days of first spray }\end{array}$ & $\begin{array}{c}26.2 \\
(30.8)\end{array}$ & $\begin{array}{c}31.9 \\
(34.4)\end{array}$ & $\begin{array}{c}29.0 \\
(32.6)\end{array}$ & 2664 & 3231 & 2947 \\
\hline 7 & $\begin{array}{l}\text { T7 - Seed treatment with carbendazim @ 2g/kg + spraying of } \\
\text { tricyclazole @ } 0.06 \%+\text { spraying of plant extract of Ocimum } \\
\text { sanctum@ } 15 \% \text { after } 7 \text { days of first spray }\end{array}$ & $\begin{array}{c}34.1 \\
(35.7)\end{array}$ & $\begin{array}{c}44.1 \\
(41.6)\end{array}$ & $\begin{array}{c}39.1 \\
(38.7)\end{array}$ & 2556 & 2735 & 2646 \\
\hline 8 & $\begin{array}{l}\text { T8 - Seed treatment with carbendazim @ 2g/kg + spraying of } \\
\text { tricyclazole @ } 0.06 \%+\text { spraying of plant extract of Ocimum } \\
\text { sanctum @ } 15 \%, 7 \text { days of first spray + spraying of } \\
\text { Pseudomonas fluorescens @ } 0.4 \mathrm{~g} / \mathrm{l} \text { after } 7 \text { days of first spray }\end{array}$ & $\begin{array}{c}28.3 \\
(32.1)\end{array}$ & $\begin{array}{c}34.0 \\
(35.7)\end{array}$ & $\begin{array}{c}31.0 \\
(33.8)\end{array}$ & 2501 & 2620 & 2396 \\
\hline 9 & $\begin{array}{l}\mathrm{T} 9 \text { - Seed treatment with carbendazim @ } 2 \mathrm{~g} / \mathrm{kg}+\text { spraying of } \\
\text { tricyclazole @ } 0.06 \% \text { twice at weekly interval }\end{array}$ & $\begin{array}{c}21.9 \\
(27.9)\end{array}$ & $\begin{array}{c}22.2 \\
(28.1)\end{array}$ & $\begin{array}{c}22.1 \\
(28.0)\end{array}$ & 3809 & 4217 & 4013 \\
\hline 10 & $\begin{array}{l}\text { T10 - Control (Without seed treatment, spraying any fungicide, plant } \\
\text { extract and bio control agents) }\end{array}$ & $\begin{array}{c}45.4 \\
(42.4)\end{array}$ & $\begin{array}{c}55.3 \\
(48.0)\end{array}$ & $\begin{array}{c}50.3 \\
(45.2)\end{array}$ & 2031 & 2037 & 2034 \\
\hline & S. Em & 1.09 & 1.2 & 0.9 & 119.6 & 183.6 & 176.2 \\
\hline & $\mathrm{CD}(\mathrm{P}=0.05)$ & 3.3 & 3.5 & 2.9 & 487 & 457 & 310 \\
\hline & CV (\%) & 6.4 & 5.7 & 5.2 & 7.7 & 6.7 & 4.7 \\
\hline
\end{tabular}


Table.2 Treatment details for integrated disease management of rice blast

\begin{tabular}{|c|c|}
\hline Treatments & Treatment Details \\
\hline $\mathrm{T} 1$ & Seed treatment with carbendazim @ $2 \mathrm{~g} / \mathrm{kg}$ \\
\hline $\mathrm{T} 2$ & Resistant Variety (NLR 34449) \\
\hline T3 & $\begin{array}{l}\text { Seed treatment with carbendazim @ } 2 \mathrm{~g} / \mathrm{kg}+\text { Foliar application of } \\
\text { tricyclazole @ } 0.06 \%\end{array}$ \\
\hline $\mathrm{T} 4$ & $\begin{array}{l}\text { Seed treatment with carbendazim @ } 2 \mathrm{~g} / \mathrm{kg}+\text { foliar spray with } \\
\text { Pseudomonas fluorescens @ 0.4 g/l }\end{array}$ \\
\hline T5 & $\begin{array}{l}\text { Seed treatment with carbendazim @ } 2 \mathrm{~g} / \mathrm{kg}+\text { foliar spray with Ocimum } \\
\text { sanctum @ 15\% }\end{array}$ \\
\hline T6 & $\begin{array}{l}\text { Seed treatment with carbendazim @ } \mathrm{g} / \mathrm{kg}+\text { spraying of tricyclazole @ } \\
0.06 \%+\text { Spraying of Pseudomonas fluorescens @ } 0.4 \mathrm{~g} / \mathrm{l} \text { after } 7 \text { days of } \\
\text { first spray }\end{array}$ \\
\hline $\mathrm{T} 7$ & $\begin{array}{l}\text { Seed treatment with carbendazim @ } 2 \mathrm{~g} / \mathrm{kg}+\text { spraying of tricyclazole @ } \\
0.06 \%+\text { spraying of plant extract of Ocimum sanctum @ } 15 \% \text { after } 7 \\
\text { days of first spray }\end{array}$ \\
\hline $\mathrm{T} 8$ & $\begin{array}{l}\text { Seed treatment with carbendazim @ 2g/kg + spraying of tricyclazole @ } \\
0.06 \%+\text { spraying of plant extract of Ocimum sanctum @ 15\%, } 7 \text { days of } \\
\text { first spray + spraying of Pseudomonas fluorescens @ } 0.4 \mathrm{~g} / \mathrm{l} \text { after } 7 \text { days } \\
\text { of first spray }\end{array}$ \\
\hline T9 & $\begin{array}{l}\text { Seed treatment with carbendazim @ } 2 \mathrm{~g} / \mathrm{kg}+\text { spraying of tricyclazole @ } \\
0.06 \%+\text { second spray of tricyclazole @ } 0.06 \% \text { after } 7 \text { days of first spray }\end{array}$ \\
\hline T10 & $\begin{array}{l}\text { Control (Without seed treatment, spraying any fungicide, plant extract or } \\
\text { bio control agents) }\end{array}$ \\
\hline
\end{tabular}

\section{Kharif and Rabi 2011-12 (Pooled)}

The results of pooled data (Kharif and Rabi, 2011-12) revealed that the highest PDS $(50.3 \%)$ was observed in untreated control with significant differences with PDS in treated plots. Among the treated plots, seed treatment with carbendazim @ 2g/kg + foliar spray with $O$. sanctum @ 15\% (T5) resulted in significantly higher PDS of $44.5 \%$ followed by seed treatment with carbendazim @ 2g/ $/ \mathrm{kg}+$ spraying of tricyclazole @ $0.06 \%$ + spraying of plant extract of $O$. sanctum @ $15 \%$ (T7) (39.1\%), seed treatment with carbendazim @ 2g/kg (T1) (35.6\%) and seed treatment with carbendazim @ 2g/kg + foliar spray with P. fluorescens @ 0.4g/l (T4) (33.6\%). The lowest PDS was observed with resistant variety NLR 34449 (T2) (11.5\%) followed by seed treatment with carbendazim
@ 2g/kg + twice spraying tricyclazole @ $0.06 \%$ at seven days interval (T9) $(22.1 \%)$. The treatments involving seed treatment with carbendazim @ 2g/kg + spraying of tricyclazole@0.06\% + spraying of plant extract of $O$. sanctum @ 15\% after 7 days of first spray + spraying of $P$. fluorescens @ $0.4 \%$ (T8) $(31.0 \%)$, seed treatment with carbendazim @ 2g/kg + one spray of tricyclazole@0.06\% (T3) (30.8\%) and seed treatment with carbendazim @ 2g/kg + spraying of tricyclazole @ $0.06 \%+$ spraying of P.fluorescens @0.4\% (T6) (29.0\%) had significantly lower PDS compared to untreated control plots.

Pooled results of grain yield (Table 1) for Kharif 2011-12 and Rabi 2011-2012 revealed that maximum grain yield of $4013 \mathrm{~kg} \mathrm{ha}^{-1}$ was observed in seed treatment with carbendazim 
@ 2g/kg + twice spraying of tricyclazole @ $0.06 \%$ at 7 days interval (T9) followed by seed treatment with carbendazim @ $2 \mathrm{~g} / \mathrm{kg}+$ one spray of foliar application of tricyclazole @ $0.06 \%$ (T3) (3245 kg ha ${ }^{-1}$ ), and seed treatment with carbendazim @ $2 \mathrm{~g} / \mathrm{kg}+$ spraying of tricyclazole @ $0.06 \%$ + spraying of $P$. fluorescens @ 0.4\% after 7 days of first spray (T6) (2947 kg ha-1).

Seed treatment with carbendazim @ 2g/kg + foliar spray with $P$. fluorescens @ 0.4\%) (T4) $\left(2788 \mathrm{~kg} \mathrm{ha} \mathrm{ha}^{-1}\right)$, seed treatment with carbendazim @ $\mathrm{g} / \mathrm{kg}+$ spraying of tricyclazole @ 0.06\% + spraying of plant extract of $O$. sanctum @ 15\% after 7 days of first spray (T7) (2646 Kg ha-1), seed treatment with carbendazim alone @ 2g/kg (T1) (2592 $\mathrm{kg} \mathrm{ha}^{-1}$ ) and spraying of tricyclazole @ $0.06 \%$ + spraying of + spraying of plant extract of $O$. sanctum @ 15\% 7 days of first spray+ foiliar spray with $P$.fluorescens @ $0.4 \%$ after 7 days of first spray $+(\mathrm{T} 8)\left(2396 \mathrm{~kg} \mathrm{ha}^{-1}\right)$ were significantly superior to untreated plots but yielded lesser than the best treatments, $i$. $e$., T9 and T3. Among the treated plots lowest grain yield was obtained with seed treatment with carbendazim @ 2g/kg + foliar spray with O. sanctum @ 15\% (T5) (2220 kg ha ${ }^{-1}$ )which was on par with untreated control (T10) (2034 $\mathrm{kg} \mathrm{ha}^{-1}$ ).

Result of experiment on integrated disease management revealed that combination of seed treatment with carbendazim @2g/kg + twice spraying of tricyclazole @ $0.06 \%$ at 7 days interval showed significant decrease in the disease severity and grain yield. IDM schedule involving integration of fungicide (seed treatment and spray), biocontrol agent (spray) and plant extract (spray) resulted in significant decrease in disease severity and increase in yield compared to untreated control. However, fungicide application alone resulted in significantly lower disease severity associated with superior yield.
Yashoda et al., (2000) reported that integration of fungicidal seed treatment and spraying has been a common practice and seed treatment with carbendazim $\left(2 \mathrm{~g} \mathrm{~kg}^{-1}\right)$ in combination with 3 sprays of tricyclazole at $0.06 \%$ or 3 sprays of pyroquilon at $0.1 \%$ resulted in lowest leaf blast incidence whereas chlorothalonil has the lowest efficacy in controlling leaf blast. Hossain and Kulakarni (2001) reported that seed treatment with carbendazim $2 \mathrm{~g} \mathrm{~kg}^{-1}$ followed by 2 sprays of tricyclazole $(0.06 \%)$ was found best in managing the disease. The next best treatment was seed treatment with carbendazim $\left(2 \mathrm{~g} \mathrm{~kg}^{-}\right.$ ${ }^{1}$ ) followed by two sprays of propiconazole $(0.1 \%)$ which was superior to hexaconazole. Ramanathan et al., (2002) stated that, Integrated Disease management is the best way to control the abovementioned diseases. The concern is to maintain the health of the crops. Chemical control generally dominates the IDM. Crop health surveillance is a good strategy within the IDM system. It involves a thorough monitoring system to check prevalence and severity of disease. It may be a onetime activity or a regular periodical activity. Surveillance activity also helps in identifying potential disease in early stages so that corrective action may be taken. Hai et al., (2007) reported that management of rice blast needs integration of all available techniques including resistant varieties and proper cultural practices followed by timely application of fungicides. Le et al., (2007) stated that management of rice blast needs integration of all available techniques including resistant varieties and proper cultural practices followed by timely application of fungicide. Muralidharan and Dinaker (2007) reported that, there was a great reduction in neck blast incidence by using tricyclazole or carbendazim in plots with resistant variety as border crop compared to plots with susceptible variety border and the application of tricyclazole increased yield by 41 and $87 \%$ in 2000 and 2001 respectively. 


\section{References}

Dinakar, C and Muralidharan, K. 2007. Measurement of leaf blast lesions and spores produced by Pyricularia grisea in commercial rice cultivars. Journal of Mycology and Plant Pathology. 37(3):401-409.

Hai, L.H, Kim, P.V., Pham Van, P.V., Thui, T.T.T and Than, D.N. 2007. Grain yield and grain milling quality as affected by rice blast disease (Pyricularia grisea) at my Thanhnam, Cailay and Tien Giang. Omonrice. 15:102-107

Hossain, M.M and Kulakarni, S. 2001. In vitro evaluation of fungicides and neem based formulations against blast of rice. Journal of Maharashtra Agricultural University. 26 (2):151-153.
Le, H.H., Pham, V.K., Pham, V.D., Tran, T.T.T and Duong, N.T. 2007. Grain yield and grain milling quality as affected by rice blast disease (Pyricularia grisea) at my Thanhnam, Tiengiang. Omonrice. 15:102-107.

Ramanathan, A., Shanmugam, V., Raghuchander, $\mathrm{T}$ and Samiyappan, $\mathrm{R}$. (2002). Induction of systemic resistance in ragi against blast disease by Pseudomonas fluorescence. Annals of Crop Protection Society. 10:313-318.

Yashoda, H., Palakshappa, M.G., Kaplappanavar, I.K., Mohan Kumar, S.D., Angadi, V.V and Hegde, Y. 2000. Chemical control of blast of rice caused by Magnaporthe grisea under rain fed direct seeded conditions in Karnataka. Karnataka Journal of Agricultural Sciences. 13(2):372-375.

\section{How to cite this article:}

Varaprasada Rao, Ch. and Anil Kumar, P. 2018. Integrated Disease Management of Rice Blast Caused by Pyricularia grisea (Sacc.). Int.J.Curr.Microbiol.App.Sci. 7(03): 2952-2958. doi: https://doi.org/10.20546/ijcmas.2018.703.341 